\title{
PATHOLOGICAL STUDY OF CLARIAS GARIEPINUS (BURCHELL, 1822) SUB-ADULT ARTIFICIALLY INFECTED WITH PSEUDOMONAS AERUGINOSA
}

\author{
AMREVUAWHO, M.O. ${ }^{1 *}$; AKINYEMI, A.A. ${ }^{1}$;EZERI, G.N.O. ${ }^{1}$; BANKOLE, O.M. ${ }^{2}$ \& TAKEET, O.V.A. ${ }^{3}$; \\ 1 - Department of Aquaculture and Fisheries Management, College of Environmental Resources \\ Management, Federal University of Agriculture, Abeokuta, Ogun State, Nigeria. \\ 2 - Department of Microbiology, College of Natural Sciences, Federal University of Agriculture, \\ Abeokuta, Nigeria \\ 3 - Department of Medicine and Surgery, College of Veterinary Medicine, Federal University of \\ Agriculture, Abeokuta, Ogun State, Nigeria \\ *Corresponding author: call4mavis@yahoo.com
}

\begin{abstract}
Amrevuawho, M.A.; Akinyemi, A.A.; Ezeri, O.G.N.; Bankole, O.M.; Takeet, O.V. (2014) Pathological study of Clarias gariepinus (Burchell, 1822) sub-adult artificially infected with Pseudomonas aeruginosa. Braz. J. Aquat. Sci. Technol. 18(2): X-X. elSSN 1983-9057. DOI: 10.14210/bjast.v18n2.p65-70 Hematology and histopathological variations in Clarias gariepinus sub-adults subjected to oral challenge with Pseudomonas aeruginosa ATCC27853 were studied for a period of 21 days, with a view to assess the pathogenesis of the bacteria and compared with a control. The results were compared statistically using One-way ANOVA. The symptoms of the infected fish included tail and fin rot, internal hemorrhages and skin patches of superficial ulcers. Tissue sections revealed marked loss and sloughing off of the gill lamellar epithelium, liver showed that hepatocytes appear finely reticulated and foamy; however there were a few foci of large cytoplasmic vacuolations of the hepatocytes and the sinusoids were moderately congested while the intestine showed shortened rugae; the submucosa glands were reduced in numbers; however the surface epithelial cells appeared to be proliferating rapidly and immature (hyperplastic). There was a significant reduction in the mean values of packed cell volume from $34.67 \pm 5.2 \%$ to $22.33 \pm 0.3 \%$, hemoglobin from $9.77 \pm 0.2 \mathrm{~g} / \mathrm{dL}$ to $6.97 \pm 0.2 \mathrm{~g} / \mathrm{dL}$, red blood cell from $2.23 \pm 0.3 \times 10^{12} / \mathrm{L}$ to $1.27 \pm 0.1 \times 10^{12} / \mathrm{L}$ and lymphocyte count from $69.00 \pm 2.3 \%$ to $52.33 \pm 0.9 \%$ of $C$. gariepinus after three weeks of exposure to $P$. aeruginosa. However, the reverse was the case in the mean values obtained for white blood cell and neutrophil for infected fish which were reasonably higher when compared to that of uninfected fish $\left(17.13 \pm 0.5\right.$ to $\left.10.80 \pm 0.3 \times 10^{9} / \mathrm{L}\right)$ and $(47.33 \pm 1.2 \%$ to $30.33 \pm 2.9 \%)$ respectively. It could therefore be concluded that changes in organs and blood parameters of fish occur proportionately to pathogen invasion.
\end{abstract}

Key words: Hematology, histopathology, pathogenesis, Pseudomonas aeruginosa

\section{INTRODUCTION}

Aquaculture/Mariculture which is the culture of the fin fish, crustaceans, mollusks and algal plants is one of the rapidly growing agricultural sectors. Different kinds of marine and fresh water fish have been cultured and the worldwide production of farmed fish is increasing every year. Global aquaculture production doubled between 1987 and 1997 (FAO, 1999) and rose from 28.6 million metric tons in 1997 to more than 37 million metric tons in 2001 (FAO, 2001). In Nigeria, aquaculture production increased from 25.3 thousand metric tons to more than 85 thousand metric tons in 2007 (FDF, 2008) and to 200 thousand metric tons in 2012 (FAO, 2013). However, with the continued expansion of cultured fish and shell fish species, aquaculture has become a key component of the animal health industry.

Of all the microorganisms responsible for diseases in fish culture, studies have shown that bacteria are responsible for high mortality in fish hatchery worldwide. Pseudomonas aeruginosa is a common bacterium that can cause diseases in animals, including humans. It is a gram-negative, anaerobic, pink-red rod-shaped and polar-flagellate bacterium with unipolar motility. It is an opportunistic pathogen to both plants and animals (Iglewski, 1996). It belongs to the family Pseudomonaceae and a type species of the genus Pseudomonas (Migula). Although $P$. aeruginosa are classified as aerobic organisms; they are considered by many as facultative anaerobes due to their ability to adapt well and proliferate in conditions of partial or total oxygen depletion. $P$. aeruginosa are widespread in nature and were observed early in the history of microbiology. It is the most common of the Pseudomonaceae family and is found to be the second most common cause of nosocomial disease. Studies have shown that at low phosphate levels, $P$. aeruginosa is activated from symbiont to express lethal toxins inside the intestinal tract and severely damage or kill the host. $P$. aeruginosa is both invasive and toxigenic. Pathology attributed to members of the motile Pseudomonads 
includes Pseudomonas septicemia, skin ulceration, tail and fin hemorrhage etc.

Blood, a specialized body fluid in animals delivers necessary substances such as nutrients and oxygen to the cells and transports metabolic waste products away from those same cells. It is composed of plasma and several kinds of cells (occasionally called corpuscles). They include: erythrocytes (red blood cells, RBCs), leukocytes (white blood cells), and thrombocytes (platelets). Blood plays an important role in the immune system of every organism. Therefore, changes in blood parameters can be used as a major determinant of the health status of the organism.

In this study, effects of $P$. aeruginosa on the hematological parameters and histology of Clarias gariepinus sub-adults were examined.

\section{MATERIALS AND METHODS}

\section{Collection of experimental fish}

A total of 60 C. gariepinus sub-adult with $200 \mathrm{~g}$ average weight, were obtained from a reputable commercial fish farm in Abeokuta metropolis and transported using kegs to the experimental site. Experimental fish were acclimatized for seven days before commencement of research work. Experimental fish were randomly divided into two treatments (control and infected) and replicated three times.

\section{Collection of typed culture of micro organism (Pseudomonas aeruginosa)}

A typed culture of Pseudomonas aeruginosa of the strain ATCC 27853 was collected from the National Veterinary Research Institute, Vom, Jos, Plateau state, Nigeria.

\section{Hematological Test}

A volume of $0.5 \mathrm{~mL}$ blood was collected from experimental fish above the lateral line using $2 \mathrm{~mL}$ needle and syringe. Blood samples were estimated for packed cell volume (PCV), hemoglobin (HB), red blood cell count (RBC), total white blood cells count (WBC), white blood cell differential: leucocyte count for neutrophil, lymphocytes, eosinophil, basophil and monocyte. This was done to ascertain the immune sta-
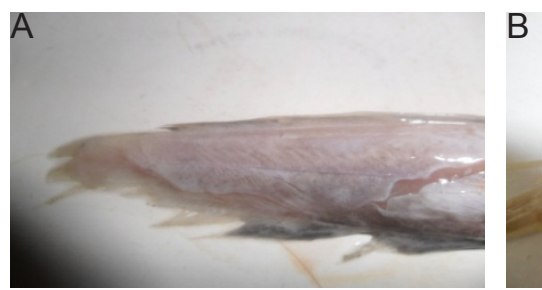

Figure 1. External signs and symptoms of infection in Clarias gariepinus sub-adults infected with Pseudomonas aeruginosa: (a) tail and fin rot (b) internal hemorrhage (c) skin patches of superficial ulcers exhibited by Pseudomonas aeruginosa infected fish. tus of the fish before challenge and after experimental fish started exhibiting signs of infection.

\section{Histological Techniques}

Fish organs (gill, liver and stomach) were collected from experimental fish and fixed in $10 \%$ formalin for preservation, dehydrated in different levels of alcohol (70\%-100\%) in descending order. The tissues were then cleared in xylene, embedded in paraffin wax, sectioned and stained with Hematoxylin and Eosin (H\&E) (Bancroft and Cook, 1994)

\section{Challenge Experiment}

A 10 -fold serial dilution of $P$. aeruginosa was prepared and aliquots $(0.1 \mathrm{ml})$ containing $10^{6} \mathrm{cells} / \mathrm{ml}$ of overnight broth culture of bacterial pathogens was then introduced into experimental fish orally and allowed to stand for about $5 \mathrm{~min}$ to observe its physiological stability and then released into the controlled environment. Experimental fish was observed daily for 21 days for signs of abnormality. Mortalities were recorded and ten fish each were examined pathologically

\section{Statistical analysis}

All data were analyzed using One-way ANOVA. Duncan multiple range tests were used to evaluate difference between treatment means. All analyses were run on the computer using the Statistical Package for Social Sciences (SPSS) program.

\section{RESULTS}

\section{External signs and symptoms of infection}

Three weeks (21 days) after exposure, experimental fish exposed to $P$. aeruginosa began exhibiting some signs and symptoms of infection such as discoloration of the skin due to the development of different patches of hemorrhagic and ulcerative skin; the tail and fins started rotting although skin lesions were superficial (Figure 1).

\section{Histopathological changes in the organs}

Tissue examination revealed an invasive action of the bacteria pathogen on the organs and tissues of the diseased fish whereas no observable effect was noticed on the organs and tissues of the unin- 

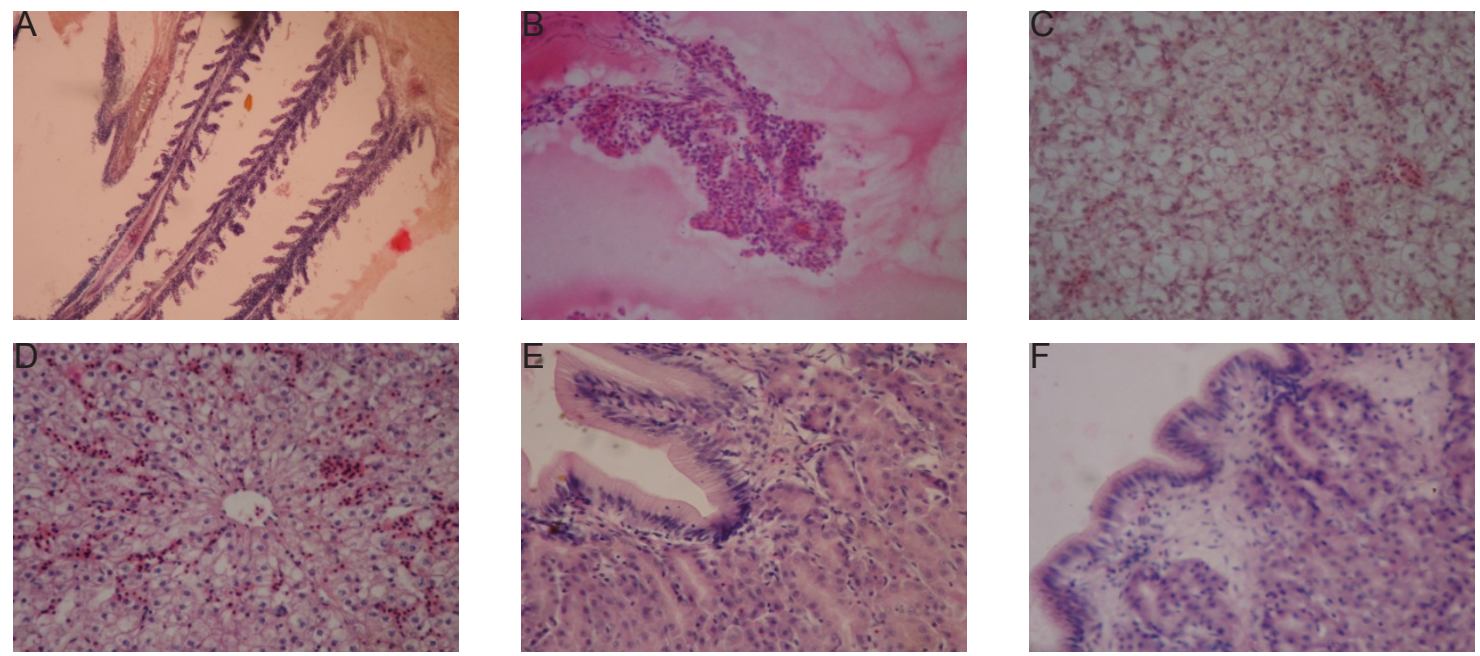

Figure 2 - Histopathological changes in the organs of Clarias gariepinus sub-adults infected with Pseudomonas aeruginosa: (a) Photomicrograph of the gills showed no visible lesion in the gills of uninfected C. gariepinus (100x magnification). (b) Photomicrograph of the gills showed marked loss and sloughing off of the gill lamellae and epithelium of infected fish. (c) Photomicrograph of the liver of uninfected fish showed that the liver had a few foci of hepatocytes containing variably-sized cytoplasmic vacuoles. (d) Photomicrograph of the liver showed that the hepatocytes appear finely reticulated and foamy; there are however a few foci of large cytoplasmic vacuolations of the hepatocytes; the sinusoids are moderately congested. (e) Photomicrograph of the stomach of uninfected fish showed no visible lesions, the rugae are of sufficient height and have a mature tall columnar surface epithelium. (f) Photomicrograph of the stomach of infected fish showed that the ruggae are shortened; the submucosal glands are reduced in numbers; however the surface epithelial cells appear to be proliferating rapidly and immature (hyperplastic) (400x magnification).

fected (control) fish. Gills of $P$. aeruginosa infected $C$. gariepinus showed marked loss and sloughing off of the gill lamellar epithelium while the gill of uninfected experimental fish showed no sign of visible lesion. Upon examination, the liver of infected experimental fish exhibited a few foci of large cytoplasmic vacuolations of the hepatocytes and also the sinusoids were moderately congested while for the uninfected fish, the liver exhibited a few foci of hepatocytes containing variably-sized cytoplasmic vacuoles. The photomicrograph of the stomach of experimental fish exposed to the bacteria pathogen showed that the rugae are shortened; the submucosa glands are reduced in numbers; however the surface epithelial cells appear to be proliferating rapidly and immature (hyperplastic) but this was not the case with uninfected fish which exhibited no visible lesions, the rugae are of sufficient height and have a mature tall columnar surface epithelium at a $400 x$ magnification as shown in the photomicrograph of the organs in Figure 2.

\section{Haematological status}

There was a significant reduction in the mean values of packed cell volume (PCV) from $34.67 \pm 5.2 \%$ to $22.33 \pm 0.3 \%$, hemoglobin from $9.77 \pm 0.2 \mathrm{~g} / \mathrm{dL}$ to $6.97 \pm 0.2 \mathrm{~g} / \mathrm{dL}$, red blood cell (RBC) from $2.23 \pm 0.3 \times 10^{12} / \mathrm{L}$ to $1.27 \pm 0.1 \times 10^{12} / \mathrm{L}$ and $\mathrm{lym}-$ phocyte count from $69.00 \pm 2.3 \%$ to $52.33 \pm 0.9 \%$ of $C$. gariepinus after three weeks of exposure to $P$. aeruginosa however, the reverse was the case in the mean values obtained for white blood cell (WBC) and neutrophil for infected fish which were reasonably higher when compared to that of uninfected fish $(17.13 \pm 0.5$ to $10.80 \pm 0.3 \times 10 \% / L)$ and $(47.33 \pm 1.2 \%$ to $30.33 \pm 2.9 \%)$ respectively (Table 1$)$.

\section{DISCUSSION}

Experimental fish showed external signs and symptoms such as discoloration of the skin which could be due to the development of different patches of hemorrhagic and ulcerative skin; tail and fin rot and skin lesions were superficial. Result of the external examination of the disease was much restricted to fins and skin which could be due to the well documented pathogenicity mechanism induced by the $P$. aeruginosa heat stable proteases (Austin \& Austin, 2007; Thune et al.,1993). Such potent proteases are effective proteolytic agents that directly liquefy the proteinacious material (hyaluronic acid and collagen) in the cement

Table 1 - Comparison of the mean values of the different blood parameters of Clarias gariepinus sub-adults exposed to Pseudomonas aeruginosa. Values are expressed in means \pm SE. Means having same letter in the same row are not significantly different at $p>0.05$

\begin{tabular}{lrr}
\hline \hline Blood parameters & \multicolumn{1}{c}{ Uninfected } & \multicolumn{1}{c}{ Infected } \\
\hline PCV $(\%)$ & $34.67 \pm 5.2^{\mathrm{a}}$ & $22.33 \pm 0.3^{\mathrm{b}}$ \\
HB $(\mathrm{g} / \mathrm{dL})$ & $9.77 \pm 0.2^{\mathrm{a}}$ & $6.97 \pm 0.2^{\mathrm{b}}$ \\
RBC $\left(\times 10^{12} / \mathrm{L}\right)$ & $2.23 \pm 0.3^{\mathrm{a}}$ & $1.27 \pm 0.1^{\mathrm{b}}$ \\
WBC $\left(\times 10^{9} / \mathrm{L}\right)$ & $10.80 \pm 0.3^{\mathrm{a}}$ & $17.13 \pm 0.5^{\mathrm{b}}$ \\
NEU $(\%)$ & $30.33 \pm 2.9^{\mathrm{a}}$ & $47.33 \pm 1.2^{\mathrm{b}}$ \\
LYM $(\%)$ & $69.00 \pm 2.3^{\mathrm{a}}$ & $52.33 \pm 0.9^{\mathrm{b}}$ \\
MON $(\%)$ & $0.00 \pm 0.0^{\mathrm{a}}$ & $0.33 \pm 0.3^{\mathrm{a}}$ \\
EOS $(\%)$ & $0.00 \pm 0.0^{\mathrm{a}}$ & $0.00 \pm 0.0^{\mathrm{a}}$ \\
BAS $(\%)$ & $0.67 \pm 0.7^{\mathrm{a}}$ & $0.00 \pm 0.0^{\mathrm{a}}$ \\
\hline \hline
\end{tabular}


substance that links cells together with an ultimate result of skin ulcers and fin rot. Similar result was also obtained in the findings of Rehab Mohamed (2010), who in his study on the bacteriology of Pseudomonas microorganisms on cultured Oreochromis niloticus, C. gariepinus and Mullet (Mugil spp.) reported hemorrhages on several parts of the body surface mouth, base of the fins, abdomen, opercula and around the anal opening, turbidity of the eyes and slight exophthalmia, roughness of the scales and sometime scaleless areas were found.

Histopathological changes observed in diseased fish shows that $P$. aeruginosa invasion affects the fish internal organs such as gills, intestines and liver. This corroborates the result of Okpokwasili \& Alapiki (1990), who recorded high count of bacteria in the liver, kidney and diseased parts of tilapia reared in the tropics. The gills are the primary initial target of toxicity, and the cytological changes in gills morphology in fish usually occur as a result of contaminant exposure Alaa et al. (2012). The erosion observed in gill of fish infected with $P$. aeruginosa in this investigation may cause a drastic reduction in the respiratory surface area meaning impairment of gaseous exchange between the fish and its environment and likely build-up of nitrogenous waste, ions etc. in the gills and ultimately body of the fish which if not treated can result to eventual death of the fish. El-Sayyad et al. (2010) in their study reported that gills of $C$. gariepinus exposed to Flavobacterium columnare were considerably altered including hypertrophy, hyperplasia of epithelial cells, necrotic changes and rupture. Ogbulie \& Okpokwasili (1999) reported necrosis leading to structural collapse and erosion of the tissues of infected C. gariepinus. According to Peuranen et al. (1994) any discontinuity of epithelial lining of the gill lead to a negative ion balance and to changes in the hematocrit and mean cellular hemoglobin values of the blood. The findings of Sahoo et al. (2000) are not consistent with the result obtained in this study. In their research, they observed that the gill of Anabas testudineus exposed to Edwardsiella tarda showed no remarkable changes. Erosion of the gill epithelium would not only decrease the surface area available for oxygen diffusion but would increase the oxygen distance between water and blood which in turn could cause tissue hypoxia (Cerqureira \& Fernandes, 2002).

Result from this research showed that the rugae of infected fish are shortened meaning that the gastric mucosa was affected thereby reducing the quantity of mucus secretions thus exposing the stomach to microbial invasion, poor digestion of food and less area available for absorption and thus small food taken in per time, malnutrition, etc. The gastric glands, home of two types of secretory cells: the parietal cells and chief cells in infected fish appeared to be reduced in number thus limiting the secretory activities of the parietal cells and thus reducing the acidic nature of the stomach which makes it impossible to kill most of the microbes ingested with food. This was not the case with $A$. testudineus exposed to $E$. tarda that showed no appreciable changes in the stomach as reported by Sahoo et al. (2000)

The liver of healthy fish showed few foci of hepatocytes containing varying sizes of cytoplasmic vacuoles however, with the invasion of $P$. aeruginosa, the liver revealed marked degeneration of the hepatocytes due to the inability of the liver to detoxify the foreign body. Hepatocyte injury often results in liver dysfunction. The findings of this research are in agreement with that by Ogbulie \& Okpokwasili (1999), who observed changes in the organs of bacterial infected fish. Most forms of liver injury involve hepatocytes as either a primary or secondary target. Congestion in the sinusoid of infected fish means sinusoidal obstruction syndrome (DeLeve, 2007) i.e. poor exchange of oxygen, carbon dioxide, nutrients, proteins and wastes. Onuoha (2010) in his research reported that $C$. gariepinus exposed to Euclinostomum clarias Metacereaciae showed hyperemia and hemorrhages, necrosis of the hepatocytes, mild bile ducts hyperplasia and moderate to severe infiltration of the periductular spaces. Continuous liver injury results in liver failure and eventually death.

The result of the study clearly demonstrated that the hematological parameters of uninfected and infected experimental fish were significantly different $(p>$ $0.05)$. There was a significant difference in the packed cell value (PCV) of $C$. gariepinus sub-adult artificially infected with $P$. aeruginosa and the uninfected juvenile fish $(p<0.05)$. Percentage PCV decreased significantly in the infected fish compared to that of the uninfected fish $(22.3 \pm 0.33 \%$ and $34.7 \pm 5.24 \%)$, respectively. Findings from this study are in agreement with the findings of Sivagurunathan et al. (2011) who reported a decrease in the percentage PCV of Cirrhinus mrigala exposed to $P$. aeruginosa. In another study with result in agreement with the result of this study is previous study by Ogbulie \& Okpokwasili (1999), who reported that higher PCV percent was associated with apparently healthy fish samples than infected fish and that there was significant difference between the groups. Also, Yavuscan et al. (2005) in their study reported that there was a significant reduction in the PCV of eel (Anguilla anguilla) spontaneously infected with $A$. hydrophila. Sebastiao et al. (2010) reported that there was no significant difference in PCV of Nile tilapia (O. niloticus) naturally infected with Flavobacterium columnare and uninfected Nile tilapia although, there was a slight decrease in this blood parameter. 
However, there is variance in the result obtained from this study with earlier study by Akinyemi et al. (2012), who reported that there was no significant difference in the PCV of $C$. gariepinus brood stock fish naturally infected with bacteria and uninfected brood stock. Reasons could be as a result of difference in sizes of fish used in the experiment.

Decrease in the percentage PCV in this study indicates that hematopoiesis (process of red blood cell formation in the blood forming tissues of the body) may be severely affected as a result of bacterial infection.

Percentage hemoglobin was significantly different between experimental fish infected with $P$. aeruginosa and uninfected fish $(p<0.05)$ with mean values of $6.9 \pm 0.2$ and $9.8 \pm 0.2$, respectively. Results obtained are in agreement with the findings of Ogbulie \& Okpokwasili (1999), who reported similar results in their study. Also, Karuthapardi \& Xavier (2010) reported that there was a sharp decrease in the mean value of HB in Tilapia when infected with Vibrio anguillarum. Similar decrease was recorded in HB value of Cyprinus carpio infected with Flavobacterium columnare (Tripathi et al.2005).

Similar result was also obtained in the RBC of experimental fish. There was a significant decrease in the total red blood cell count of $C$. gariepinus sub-adult exposed to $P$. aeruginosa in comparison to uninfected fish $(p<0.05)$ with mean values of $1.3 \pm 0.1$ and $2.2 \pm 0.3$, respectively. This result corroborates the findings of Bektas and Ayik (2009), who reported that there was a significant decrease in RBC count of $P$. putida infected rainbow trout (Oncorhynchus mykiss). Sebastiao et al. (2010) in their study reported that there was a significant difference in the total red blood cell count of Nile tilapia (O. niloticus) naturally infected with F. columnare and uninfected fish. This finding was also corroborated by the findings of this research.

Result from this study is at variance with the finding of Manoj et al. (2010), who reported a significant increase in RBC count on infected fish. Another research which contradicts the findings of this study is earlier research by Zorriehzarah et al.(2009), who reported that there is no significant difference in the RBC count of infected and uninfected rainbow trout (O. mykiss) fry.

The RBC contains hemoglobin, an iron containing protein, which facilitates transportation of oxygen by reversibly bonding with this respiratory gas thereby increasing its solubility in blood. The hematocrit (PCV) percentage, hemoglobin and RBC are good indicators for oxygen transportation capacity of fish, thus making it possible to establish relationship with the oxygen concentration available in the environment and the health of the fish. In the present study, the reductions in the total red blood cell count, PCV percent and hemoglobin rate indicates that the oxygen carrying capacity of the fish was impaired by the bacteria.
The difference in the mean value of the white blood cell count (WBC) between uninfected and infected fish was significant $(p<0.05)$. White blood cell count was higher in the infected fish than in the uninfected fish at $17.2 \times 10^{\circ} \mathrm{L}$ and $10.8 \times 10^{\circ} \mathrm{L}$ respectively. The reason is that WBC being on the front line of the body defense system is activated when the body is invaded by pathogen so as to fight against the invasion (Ganong, 2005). Also, the findings of this study are in agreement with the result obtained in earlier research by Manoj et al.(2010), who reported that Labeo rohita infected with $A$. hydrophyla had a higher WBC than uninfected fish. Similar results were also recorded in the study of Sivagurunathan et al. (2011), who reported that the WBC of Cirrhinus mrigla exposed to $P$. aeruginosa was higher compared to uninfected fish.

The mean values of neutrophil and lymphocyte were significantly altered in infected C.gariepinus $30.33 \pm 2.9 \%$ to $47.33 \pm 1.2 \%$ and $69.00 \pm 2.3 \%$ to $52.33 \pm 0.9 \%$ respectively. However, there was no significant difference in the mean of monocyte, basophil and eosinophil. Differential WBC was reported in the study of Zorriehzarha et al.(2009) to be significantly different in infected Rainbow trout (O. mykiss) fry with percentage lymphocytes and neutrophil lower in the infected fish as compared to the findings of this study with lower neutrophil percent observed in the uninfected experimental fish.

\section{CONCLUSION}

In conclusion, results obtained from this research shows the invasive nature of $P$. aeruginosa not only on the external features of the fish but also on the internal organs and blood parameters. The state of both the internal organs and blood parameters of an organisms are the major indicators of the health of that organism thus the significant difference observed between the infected and uninfected fish is a major indicator of the virulent nature of $P$. aeruginosa. Stressors including overcrowding, high temperature, a sudden change of temperature, rough handling, transfer of fish, poor nutritional status contribute to physiological changes and exacerbate susceptibility to bacterial infection. Thus, there is need for farmers to adhere to good management practices and adequate feeding so as to reduce disease outbreak to the barest minimum.

\section{REFERENCES}

Akinyemi, A.A.; Agbon, A.O.; Adeosun, F.I.; Abdul, W.O. \& Idowu, A.A. 2012. Haematological parameters of infected and non-infected cultured Clarias 
gariepinus (Burchell, 1822) brood stock. J. Sci. Multidisc. Res., 4: 47-55.

Alaa El-Din, H.S.; Imam, A. M. \& Usama, M.M. 2012. Histopathological alterations in some body organs of adult Clarias gariepinus (Burchell, 1822) exposed to 4-nonylphenol. In: García, M.-D. (ed.) Zoology. DOI: 10.5772/29544

Austin, B. \& Austin, D.A. 2007. Bacteria Fish Pathogens: Disease of Farmed and Wild Fish. Praxis Publishing, UK. 581pp.

Bancroft, J.D. \& Cook, H.C. 1994. Manual of histological techniques and their diagnostic application. Churchil Livinstone publishers. 457pp.

Bektas, S. \& Ayik, O. 2009. Haematological parameters and erythrocytes osmotic fragility in Rainbow trout (Oncorhynchus mykiss) experimentally infected with Pseudomonas putida. Journal of Fisheries and Aquatic Science, 4: 246-253.

Cerqureira, C.C.C. \& Fernandes, M.N. 2002. Gill tissue recovery after copper exposure and blood parameter response in the tropical fish Prochilodus scofa. Ecotox. Environ. Saf. 52: 83-91.

De Leve, L.D. 2007. Hepatic microvasculature in liver injury. Semin. Liver Dis. 27: 390-400.

El Nagar, R.M.A. 2010. Bacteriological studies on Pseudomonas microorganisms in cultured fish. Master thesis, Department of Bacteriology, Mycology and Immunology, Zagazig University, 94pp.

El Sayyad, H.I.; Zaki, V.H.; El Shebby A.M. \& El Badry D.A. 2010. Studies on the effect of bacteria diseases on the skin and gill structure of Clarias gariepinus in Dakahlia province, Egypt. An. Biol. Res. 1(4): 106-118.

Federal Department of Fisheries 2008. Fisheries statistics, FDF, Abuja, Nigeria.

Food and Agricultural Organization 1999. State of the world fisheries and aquaculture. Rome, Italy.

Food and Agricultural Organization 2001. State of the world fisheries and aquaculture. Rome, Italy.

Food and Agricultural Organization 2013. State of the world fisheries and aquaculture. Rome, Italy.

Ganong, W.F. 2005. Review of Medical Physiology. $22^{\text {nd }}$ ed. Singapore: McGraw Hill; 515-517.

Iglewski, B.H. 1996. Pseudomonas. In: Baron, S. (ed.) Medical Microbiology. $4^{\text {th }}$ edition. University of Texas Medical Branch at Galveston. Chapter 27.

Karuthapardi, M. \& Innocent, X.B. 2010. Immune response of Tilapia mosambicus administered with rat serum vaccine for Vibrio anguillarum. Current Biotica, 4(1): 63-72.

Manoj, C.K.; Mohanakumaran C.; Patel, M.R. \& Salim K.R. 2010. Haematobiochemical and histopathological changes in Labeo rohita infected with Aeromonas hydrophila by immersion challenge. Fish. Technol. 47(2).

Ogbulie, J.N. \& Okpokwasili, G.C. 1999. Haematological and histological responses of Clarias gariepinus and Heterobranchus bidorsalis to some bacterial diseases j in Rivers state, Nigeria. J. Natn. Sci. Foundation Sri Lanka, 27(1): 1-16.

Okpokwasili, G.C. \& Alapiki, A.M. 1990. Bacterial flora associated with a Nigerian fresh water fish culture. J. Aquac. Tropics, 5: 87-90.

Onuoha, E.O. 2010. Liver pathology of the African catfish (Clarias gariepinus) infected with Euclinostomum clarias metacereariae in Anambra River Basin, Nigeria. Ann. Res. Intern., 7(1): 1151-1155.

Peuranen, S.; Vuorinen, P. J.; Vuorinen, M. \& Hollender, A. 1994. The effect of iron, humic acids and low $\mathrm{pH}$ on the gills and physiology of brown trout (Salmotrutta). Ann. Zool. Fennicii, 31: 389-396.

Sahoo, P.K.; Swain P.; Sahoo, S.K.; Makherjee, S.C. \& Sahu, A.K. 2000. Pathology caused by the bacterium Edwardsiella tarda in Anabas testudineus (Bloch). Asian Fish. Sci.,13: 357-362.

Sebastiao, F.A.; Nomura, D.; Sakabe, R. \& Pilarski, F. 2011. Haematology and productive performance of Nile Tilapia (Oreochromis niloticus) naturally infected with Flavobacterium columnare. Braz. J. Microb., 42: 282-289.

Sivagurunathan, A.; Amila Meera K. \& Xavier, B.I. 2011. Investigation of immunostimulant potential of Zingiber officinale and Curcuma longa in Cirrhinus mrigalla exposed to Pseudomonas aeruginosaHaematological assessment. Int. J. Res. Ayurveda and Pharm., 2(2): 899-904.

Thune, R..L.; Stanley, L.A. \& Cooper, R.K. 1993. Pathogenesis of gram-negative bacterial infections in warmwater fish. Ann. Rev. Fish. Dis., 3: 37-68.

Tripathi, N.K.; Latimer, K.S.; Gregory, C.R.; Ritchie, B.W.; Wooley, R.E. \& Walker, R.L. 2005. Development and evaluation of an experimental novel of cutaneous columnaris disease in Koi (Cyprinus carpio). J. Vet. Diag. Invest., 17: 45-54.

Yavuzcan, Y.H.; Bekcan, S.; Karusu, B.A.C. \& Akan, M. 2005. Some blood parameters in eel (Anguilla anguilla) spontaneously infected with Aeromonas hydrophila. Israel J. of Vet. Med., 291-292.

Zorriehzahra, M.J.; Hussain, M.D.; Gholizadeh, M. \& Saidi, A.A. 2011. Study of some haematological and biochemical parameters of Rainbow trout (Oncorhynchus mykiss) fry in Western part of Mazandaran province, Iran. J. Fish. Sci. 9(1): 185-198.

Submetido: Junho/2013 Revisado: Outubro/2013 Aceito: Fevereiro/2014 